\title{
Diaspora without Homeland: Slave Descendants and the Cultural Politics of Ancestry in the Upper Gambia River Valley
}

Une diaspora sans patrie: descendants d'esclaves et politique culturelle de

l'ascendance dans la haute vallée du fleuve Gambie

Una diáspora sin patria: los descendientes de esclavos y las políticas culturales

de ascendencia en el Alto Valle del río Gambia

\section{Paolo Gaibazzi}

\section{(2) OpenEdition}

\section{Journals}

Electronic version

URL: https://journals.openedition.org/remi/6253

DOI: $10.4000 /$ remi.6253

ISSN: $1777-5418$

\section{Publisher}

Université de Poitiers

\section{Printed version}

Date of publication: 1 March 2013

Number of pages: $23-43$

ISBN: 979-10-90426-07-8

ISSN: 0765-0752

\section{Electronic reference}

Paolo Gaibazzi, "Diaspora without Homeland: Slave Descendants and the Cultural Politics of Ancestry in the Upper Gambia River Valley", Revue européenne des migrations internationales [Online], vol. 29 $n^{\circ} 1$ | 2013, Online since 01 March 2016, connection on 14 April 2022. URL: http:// journals.openedition.org/remi/6253 ; DOI: https://doi.org/10.4000/remi.6253 


\section{Diaspora without Homeland: Slave Descendants and the Cultural Politics of Ancestry in the Upper Gambia River Valley}

\section{Paolo Gaibazzi ${ }^{1}$}

The Gambia is essentially a country of immigrants. Although the Gambia River valley has been inhabited for centuries, ${ }^{2}$ each major phase of its history from the Manding conquest to the Atlantic Slave trade, the expansion of peanut cultivation, then colonialism and decolonization - has been marked by robust human and commercial mobility. Successive waves of migration have dotted the landscape with settlements of different ethnicities, religions and socioprofessional groups. Largely ignored by public debates, this migratory past of Gambians thrives in what Pierre Nora (1984) would call milieux de mémoire, a social environment where the past is brought to bear on every day and ritual life in the present, rather than in lieux de mémoire. Preserved by griots (praisesingers), oral historians and ordinary people, diasporic memories and genealogies of immigration serve especially to advance claims to customary political and religious offices in localities, and to mediate relations and allegiances with new settlers and strangers (Beedle, 1980; Bellagamba, 2004).

Not all Gambians have, however, a place in the diasporic memories that uphold the social order of the valley. Today, a large number of inhabitants are descended from slaves owned by freeborn people in the past. A widespread institution, slavery gradually died out after 1930, when the British outlawed all forms of ownership and exchange in people. ${ }^{3}$ However, slave descent has not been removed from social memory. With the exception of some groups and areas, in most of the Gambia - indeed in most neighbouring countries - descent from enslaved people still forms the basis of membership in an endogamous status group anachronistically labelled as "slaves" in the local vernaculars.

1 Research Fellow, Zentrum Moderner Orient, Kirchweg 33, D-14129 Berlin, Germany; paolo.gaibazzi@zmo.de

2These include: some Jola and Manjak speakers in the Lower Valley, some Wolof groups on the Northern banks, and some of the Pulaar speaking groups, especially in Middle and Upper River.

3 Abolition of the trans-Atlantic slave trade should not be mistaken for abolition of slavery within African territories. Also, various forms of slavery existed in West Africa prior to abolition, though West African slavery was rarely chattel-like, as commonly held in Western representations. 
Slave descendants are appended to the bottom of the social hierarchy, which is composed of equally endogamous groups of freeborn people topped by "nobles" and their client groups of "casted artisans". In the Gambia, the freeborn acknowledge that slave descendants, like themselves, come from elsewhere, but they tend to think of them as people with no ancestry.

Slave descendants possibly constitute the largest diasporic group in contemporary Gambia, if not in West Africa as a whole. ${ }^{4}$ Certainly, one should be careful not to see people of unfree origins as a homogenous category: West African slavery was internally diverse and emancipation produced disparately diverse social trajectories (Rossi, 2009). And yet, composite as it may be, this is by far the most forgotten diaspora. Stories of the displacement of slaves rarely made it into the colonial records, nor were they included in the oral traditions narrated by griots and other local oral historians. ${ }^{5}$ In contrast to the trans-Atlantic slave trade a pacified past preserved in several memorial sites and events that have no impact on national politics - the issue of slavery has not resurfaced in Gambia after abolition, except as a metaphor for European exploitation during decolonization (Bellagamba, 2009). Indeed, there is virtually no public debate about the history of slavery in Gambia and elsewhere in West Africa (Pelckmans and Hohanou, 2012).

The past of Gambian slave descendants is not simply silenced (Trouillot, 1995); it is also displaced. Whereas many Afro-Americans today think of themselves as a diaspora and identify Africa as their ancestral homeland, former slaves in West Africa can only be thought of as a diaspora without a homeland. ${ }^{6}$ In the Gambia, few people actually have documents or tangible proofs of their geographical origins. ${ }^{7}$ Certifying one's spatial and social origins is a matter of cultural politics, whereby one strives to insert one's past within accepted frames of orally transmitted history (Bellagamba, 2002). Not only have slave descendants poor recollections of their migratory past; their narratives have often limited legitimacy and consequentiality in social terms. From the point of view of the freeborn, the places of origins of their progenitors are unknown and unverifiable, to the point that remembering who former slaves are implies removing their distant origins and placing them at the point and time of their arrival, when their genealogical identity as "slaves" was forged.

Based on ethnographic and archival research ${ }^{8}$ (2006-2008, 2012), this article illustrates one aspect of this cultural politics of memory by drawing on the story

\footnotetext{
$4 \mathrm{It}$ is very hard to quantify the number of slaves. As slavery ended in 1930, they have disappeared from the official records. In the Sahel and Senegambia, slaves constituted up to $50 \%$ of the local population, and the majority stayed after abolition (Klein, 2009).

5 The griots usually assume the viewpoint of the elites. The colonial masters tended to reproduce, if at all, this viewpoint (see e.g. Rodet, 2009).

6 Writing about a very different context, Ryang and Lie (2009) have also used the expression 'diaspora without homeland'.

7 Some chiefly and clerical (i.e. literate in Arabic) families keep written records (tarika) of their genealogies and migrations. In some areas of West Africa, slave descendants preserve memories of their place of origin as a means to distinguish themselves from the freeborn (Botte, 1994: 115).

8 Research for this article was generously funded by: the University of Milano Bicocca with the Unicredit Foundation, Italy's Ministry of Foreign Affairs via Missione Etnologica in Benin e Africa Occidentale (MEBAO), and Germany's Federal Ministry of Education and Research (BMBF).
} 
of the Kamara, a large, wealthy family living in the Soninke or Serahule village of Kunda, in the Upper River Region of the Gambia. ${ }^{9}$ The Kamara are both typical and special slave descendants by West African standards. The scholarship on African slavery focuses predominantly on captives and trade slaves. In contrast, like many other slave descendants in Upper River communities, the Kamara most probably became classified as komo (the Soninke word for slaves/slave descendants) once they settled, as free migrants, in Kunda in the late nineteenth century, and their children were given women of slave descent to marry. The children of such unions would have belonged or become attached to the master of the mothers, were it not for the leaders of the family, who used their wealth to successfully redeem incoming brides and their children from slave status. However, despite having de facto no slave origins, the Kamara are still prevented from marrying freeborn women in Kunda because the freeborn think that their "true" origins are uncertain and ultimately foreign to the diasporic past of the village elites, who descend from the Soninke communities disseminated between the upper Senegal River valley and Eastern Mali.

By focusing on the narratives and silences surrounding the origins of the Kamara, this article explores the ways in which the memory of migration is interlaced with the reproduction of social distinction and inequality (Pelckmans, 2011: 53-6). Over the past twenty years, there has been a tendency in the social sciences to think of diasporic narratives as counter hegemonic discourses that disrupt the nationalist myth of blood and soil and/or allow "subaltern subjects" to articulate alternative identities and histories (see e.g. Basch, Glick Schiller and Szanton Blanc, 1994; Cohen, 1996; Kaplan, 1996). Studies of the African descendants across the Atlantic Ocean and, to some extent, across the Indian Ocean and the Sahara, have significantly contributed to such a strand of research, one of the most representative works in this scholarship being Paul Gilroy's (1993) The Black Atlantic. However, when transferred to the African continent such perspectives may lack analytical purchase. Not only have memories of the African slave trade limited impact on the national politics of the Gambia, but also the diasporic memory of continental slave descendants is in itself not anti-hegemonic, for the dominant discourses on the past are themselves diasporic. For the Kamara, becoming truly "local subjects" - subjects who belong to a situated community of kin and neighbours (Appadurai, 1996: 179) - is tantamount to claiming not autochthony but membership in a shared history of displacement. ${ }^{10}$ I thus suggest that collective memory produces social exclusion not solely through a nationalist/sedentarist rhetoric that silences cross-boundary migration (Malkki, 1995), but also through eviction from particular diasporic narratives that do not acknowledge the migrations of subaltern subjects.

Though silenced and displaced stories like the Kamara's still raise questions about the possibility of narrating history from the point of view of the marginal classes. Some scholars have argued that West African slave descendants tend to

\footnotetext{
9 In order to protect the identity of the family, I have used a pseudonym for their patronym and their village. Excerpts of an interview with Demba Kamara are published elsewhere (Gaibazzi, forthcoming-b). This essay is meant to be an analytical commentary of this and several other sources.

10 As Carola Lentz (2006: 6) has noted, land rights in West Africa are mostly granted with membership in groups based on a variety of criteria, including descent and shared histories of migration.
} 
have a partial or truncated recollection of the past. Violently uprooted from their context of origin often at a young age, and then displaced, sold and assimilated into their masters' milieu, slaves were unable to transmit the oral traditions and memories of their homeland to their descendants, who ended up borrowing those of their former masters ${ }^{11}$ (e.g. Klein, 1998: 245; Bruijn and Pelckmans, 2005: 72). The evidence presented in this article suggests that slave descendants may adopt different strategies, from silence to voice, from borrowing to manipulation. After describing the search by the Kamara for their true origins, in the second part of the article I proceed to discuss how they contest the geo-social location of their origins by appropriating the dominant discourse on ancestry, while at the same time reproducing its foundational principles. The Kamara's dispute about ancestry is mostly played out at the conscious or ideological level, whereas they rarely call into question the taken-for-granted scripts of the memory of migration. ${ }^{12}$

Far from simply endorsing the argument about the absence of historical production among slave descendants (Rodet, 2010), I would nonetheless avoid the tendency to conflate the search for subaltern voices with the search for alternative, even emancipatory, constructions of the past among slave descendants. As Gyan Prakash has argued, subalternity is not an external element to hegemony but an internal one. It identifies an intractability that "erupts within the dominant systems and marks its limits from within, that its externality to the dominant systems of knowledge and power surfaces inside the system of dominance, but only as an intimation, as a trace of that which eludes the dominant discourse" (Prakash, 2000: 288, italics in the original). What this article does is not so much to try and identify the presence or absence of the subaltern voice per se (Spivak, 1988) as to understand how the "subaltern" speaks and generates intractable elements within the hegemonic formation. Whereas the Kamara do seek emancipation by rectifying diasporic memory, I am especially interested in showing how their tribulations with certifying origins bring to the surface some of the internal limits and contradictions of the cultural politics of ancestry in the Gambia.

\section{Immigration, Slavery and Emancipation in Upper River Gambia}

During the second half of the nineteenth century, the political map of the Senegambia region was redrawn by war. This caused great havoc and displacement in the region. Though it was not free from belligerent warlords, the upper Gambia River valley was a relatively safe place to settle; one where, moreover, commercial groundnut cultivation was quickly developing. Soninke speakers made up a large proportion of the immigrants, and eventually became

11 For a partial exception to this, see Rodet (2010).

12 Building on Gramsci and R. Williams, John and Jean Comaroff (1992: 29) have distinguished between ideology and hegemony, the former being the explicit, argumentative systems of ideas of a dominant class, and the latter being the naturalized part of ideology, the unspoken conventions which orient common sense in a given political community. 
the largest ethnic group of the Upper River. ${ }^{13}$ With some exceptions, the first waves of Soninke migrants were displaced refugees from Bundu, a pre-colonial kingdom between the upper Gambia and the upper Senegal valleys, and one of the main theatres of war in the region in the second half of the nineteenth century (Gomez, 1992: 122 and 49; Clark, 1999: 99-107). Enjoying a good reputation not only as prominent traders and dedicated Islamic scholars but also as arduous cultivators, the displaced Bundu Soninke sought refuge in the communities of the northern banks, where they had commercial ties, and especially founded new villages across the river, along the southward-moving agricultural frontier (Gaibazzi, 2010). Here they were granted protection by Aplha Molo Egge, and later by his son Musa, the king of Fuladu. ${ }^{14}$ When the British annexed the Upper River to the Protectorate of the Gambia in 1901, most Soninke settlements witnessed a change of rulers, but not of rules. Although the colonialists forced some political and social changes, power structures remained essentially the same, with district and village chiefs, local dignitaries and household heads being relied upon to govern the population (Bellagamba, 2002).

Once founded, Soninke villages attracted numerous immigrants hailing from the regions of the interior. In spite of colonial pacification, refugees and various other migrants continued to arrive in the Upper River valley at the turn of the twentieth century. Improved security also favoured labour mobility for burgeoning rural and urban economies. By the 1920s, the Upper River had become the first peanut exporting region in the Gambia. Commerce was thriving, Basse Santa Su (the regional capital) quickly expanded (Barrett, 1988: 105-106), and Soninke villages experienced dramatic demographic growth. ${ }^{15}$ Thousands of so-called strange farmers (called navétanes in Senegal), seasonal migrants, came to farm groundnuts in the Gambia. ${ }^{16}$ Entire families who faced dire economic straits in the Upper Senegal valley during the first two decades of the twentieth eventually also decided to move into the peanut-growing areas (Rodet, 2009: 107-121, 248-262). Finally, relatives, fellow villagers and other people connected to the Bundu Soninke eventually joined them in their new locations along the Upper River valley.

Not all new settlers decided to integrate into the local society. Some probably maintained relations with their home communities and married people from there. Yet most villagers who are descended from immigrants of the first quarter of the twentieth century have cut off relations with their communities of origin. Because of either opportunities or constraints, at some point the first settler(s) decided to integrate. Since it is not uncommon for African lineages to recruit outsiders, within limits, it is likely that some migrants, especially women, were "adopted" into local descent groups, thus losing their previous social identities and becoming de facto members of the receiving one. Many other strangers

13 According to the 2003 census the Soninke make up 39\% of the citizenry of the Upper River Region, followed by Mandinka (31\%) and the Fulani (27\%) (Republic of The Gambia, 2006).

14 In its heyday the kingdom of Fuladu (founded in 1861) included most of the Casamance, the Southern banks of the Upper Gambia, and parts of Guinea-Bissau.

15 Gambia National Archives CSO 2/1903 (Report on MacCarthy and Upper River Provinces for the year 1940).

16 On the strange farmers in the Gambia basin, see Swindell and Jeng (2006). On Senegal, see David (1980). 
did, in contrast, retain their identity, but as strangers they faced the challenge of finding a spouse them and/or their children among people who married primarily locals and kin members.

As in many parts of the world, strangers in Kunda were, in Simmel's (1964 [1908]) sense, subjects who are in a society, but not part of it. As I showed elsewhere (Gaibazzi, 2012), many of those who had neither social connections to the villagers nor attributes associated with status groups were lumped together with people who already occupied the margins of society: slaves and freedmen. Removed from their natal kin, they relied on hosts and patrons, who often played a role in arranging marriages with either slaves or former slaves over whom they had retained influence. By marrying slave spouses, these immigrants did not become the property of their landlords, even though they often depended on the latter in times of hardship. Rather, because slave descent is transmitted through the mother's line, the children of such wedlock were classified as slave descendants (komo) "belonging" to the master of their mother.

A European reader may find it hard to make sense of why immigrants accepted being integrated as "slaves". Some clarification of the terms employed and a historical contextualization of what slavery meant to whom might help. In pre-colonial West Africa, there was a continuum between strangerhood and slave status. Virtually all definitions of slavery point out that a critical attribute of the slave was his or her social anonymity. ${ }^{17}$ Slaves were first and foremost outsiders alienated (often violently) from their own milieus and in their masters' one, they were deprived of their rights of birth over their descendants and ancestors. Orlando Patterson (1982) thus equated slavery to social death. Whereas there is disagreement on whether slaves were included as members of their masters' society (Kopytoff and Miers, 1977; Meillassoux, 1986), most scholars of African slavery agree that slaves shared a condition of strangerhood. It is also documented that famine, indebtedness and other calamities pushed strangers into slavery (e.g. Kopytoff and Miers, 1977: 12; Vaughan, 1977: 92).

In the Upper River, a grey zone between slavery and strangerhood actually developed or expanded from the end of the nineteenth century onwards. Peter Weil has shown that at this time the rulers and landlords of Wuli, a kingdom on the Northern banks of the Upper River, had begun to reduce labour dues for slaves because they began to rely on a more flexible workforce, namely the strange farmers, who worked four to five mornings (then reduced to three) for their landlords, like second generation slaves (Weil, 1984: 109-111). In the Gambia and Senegal valleys, slaves who became emancipated also began to enter into similar contractual or patron-client relations with former masters and other landlords in order to access the land (Manchuelle, 1997: 138-139; Swindell and Jeng, 2006: 118-128).

Abolitionist policies deepened the ongoing transformation of slavery. The internal trade in slaves was effectively brought to an end by the First World War, and all forms of slavery were finally abolished in 1930 (Bellagamba, 2005). Abolition was, however, confined to the legal aspects of slavery, and did not

17 Amongst the first social scientists to point this out was Henri Lévy-Bruhl (1934), who in his study on Roman jurisprudence defined slaves as 'permanent strangers'. 
address the social and economic ones. In the Upper River, the ruling elites largely remained in control of political offices and networks of patronage (ibid.: 27). Some slaves of course took advantage of the legal changes and fled or rebelled, but many others remained where they were and tried to become emancipated from their masters by gaining access to the land, building a compound for their families, and paying bridewealth either for themselves or for their children. This was not an easy task for people who had had limited social and economic freedom in the past, and the support of the former masters or of other patrons often remained indispensable. As a consequence, although by the 1950s social emancipation was virtually complete, many former slaves have since maintained ties of actual or customary dependence on their former masters.

In sum, the immigrants who settled in Kunda and the surrounding villages from the end of the nineteenth century to the mid-twentieth century were seen neither as captives nor as trade slaves, but as strangers whose social position overlapped with that of second generation slaves and freedmen in the period of abolition. Nevertheless, by entering into slavery, their descendants have not been distinguished from the descendants of slaves proper and today they find themselves confined within an endogamous status group anachronistically called komo, "slaves".

The reasons for the ongoing relevance of "slavery" are still being debated and concern us only marginally here (see Klein, 2009 for an overview). What matters is that a logic of inclusion/exclusion predicated on geo-social origins has persisted. The freeborn seem to have responded to the emancipation of slaves by monopolizing the means of social distinction and historical production. While emancipation allowed slaves to acquire social rights over the descending generations, thus overcoming social death, it rarely granted them cultural rights over the ascending generations. This is also the fate of the immigrants classified and integrated into the group of komo. As we shall see, lacking free origins does not simply mean that one's forebears were somebody's slaves; it also means lacking real or mythological ancestors in a distant land. To put it differently, although the descendants of slaves are no longer alienable properties, the process of alienation described by Patterson has continued to haunt them. Slave descendants are still separated from their past and remembered as aliens.

\section{In Search of Origins: The Kamara}

The Kamara of Kunda village provide an example of the intricacies between memory, migration and the reproduction of status boundaries. The Kamara trace their origins to one of the waves of migration that reached the Upper River at the end of the nineteenth century. Musa Kamara hailed from Southern Central Mali, probably from a Pulaar-speaking area. Once he arrived in the Upper River, he was hired as a mercenary by Musa Molo Balde, the king of Fuladu mentioned earlier. After some years, as a compensation for his services, Musa Molo gave Musa Kamara a woman called Penda to marry. As warfare waned during colonization, Musa (Kamara) and Penda settled in a recently established village, Kunda, in what had by then become a British Protectorate (1901-1965). The couple was hosted by a local family, and Musa probably farmed with them for a while before he was able to construct his own compound. Musa did not 
seek other wives in Kunda. Instead he had to find spouses for his children - two daughters and a son - when these came of age. Eventually, his two daughters married two men of slave descent (kome) and left for their husbands' villages. Not long after, somewhere in the second decade of the twentieth century, Musa died, leaving his son Mari and Penda to manage the household on their own.

Surprisingly, the small household managed to make significant progress. Mari, known as Mari Penda, was hardworking and enterprising. For a number of seasons, he managed to harvest a surplus of groundnuts and sell them. He did not sit on his money: he travelled through the Kayes area (in Mali) or to Futa Jallon (in today's Guinea) together with other Soninke and Gambian traders, and returned with textiles, which he then resold in the lower Gambia valley. In turn, Mari Penda used his profits to employ strange farmers and pay people in kind in order to help him with weeding and harvesting the fields. He went on trading and farming until the 1930s, when he began to do business at home. He mainly invested in cattle breeding and in buying and selling groundnuts.

Mari Penda became a patron in his village. Today, some fifty years after his death, many elders still have vivid memories of him. He is remembered as a wealthy and generous man who often gave oxen from his large herd as a gesture of Islamic charity. He sometimes wrote off the debts of people who had borrowed money from him or bought his produce on credit, and helped the needy. Mari Penda also befriended Islamic scholars, whose spiritual and esoteric assistance he probably sought in order to ensure the protection and prosperity of his family. In the 1950s, he was among the first people in the Upper River area to travel on a plane to Mecca, together with the district chief at that time.

Mari Penda's upward mobility was, however, partial. He was able to marry off some of his daughters to well-known clerical families. Yet neither he nor his sons have ever been able to marry freeborn women. Mari Penda married four wives, three of kome descent from Kunda and nearby villages, and one from Mali whom he purportedly found through his commercial partners. Except for his "foreign" wife, Mari Penda was, like his father, thus positioned among the komo through marriage. Ever since Mari Penda took his first wife from his affines (his sister's marital kin), the Kamara have manumitted their brides from the latter's former masters. ${ }^{18}$ Though abolition gave them legal freedom, former slaves wishing to redeem themselves from socio-moral obligations vis-à-vis their former masters are still required to advance a request to the latter together with a symbolic payment or present. Once redeemed and purified, the Kamara brides would not transmit slave descent to their children. "None of our women cook at ceremonies", a Kamara elder said to me once, thus making it clear that the Kamara owe ritual labour to nobody, in contrast to most other komo. ${ }^{19}$

More than any other family I have met in the Upper River, the Kamara epitomised the painstaking effort by people classified as slave descendants to move out of their status group. Their fellow villagers of all statuses partly acknowledged

18This is commonly done by freeborn men who marry women of slave descent. Freeborn women are not allowed to marry down the social hierarchy.

19 Men fetch firewood and butcher the sacrificial rams, while women do the cooking and assist the bride. 
the upward mobility of the Kamara: "Nobody can call them slaves!" they often told me, emphatically lowering their voices and putting a hand in front of their mouths, as if to warn me that such comments should not be voiced freely. Nobody could say that any of the Kamara, dead or alive, was "our slave", or that "we got him a wife", as members of the freeborn are sometimes heard to say when speaking of the descendants of their former slaves. This shows that, thanks to their achievements and wide-ranging patronage networks, the Kamara could to some extent silence attempts to publicly shame them by mentioning their lack of freeborn origin. And yet, if respect and caution were used in talking about the Kamara's status, at the social and practical level they were not considered by any means as freeborn. When I put it to a young man of an important noble lineage that "the Kamara are not slaves", he plainly retorted: "Do you see any noble woman in that compound?" I had to admit I did not.

The status of the Kamara is a veritable conundrum: since the Kamara are nobody's former slaves, on what basis are they associated with the komo, and thus denied freeborn women? Where does their slave descent originate from? In considering the social origins of the Kamara, the majority of my respondents questioned on such issue proceeded matrilineally, as for most slave descendants. Many of them, like my acquaintance, did not know the details of the entry of the Kamara into "slavery" and simply assumed that Mari Penda's father, or some earlier ancestor of his, married a slave woman when he settled in Kunda. The absence of noble women in their compound was, in their view, a selfevident result of that. Yet this version lacked authority, for the reasons mentioned above: no genealogies of slave descent could be found in the Kamara's past. Thus, some of the more aged and knowledgeable freeborn in Kunda supported their arguments by pointing to the marriage between Musa and Penda. They remarked that Penda was a slave or a slave descendant from Musa Molo's large entourage of servants; even if she had been Musa Molo's own daughter, as the Kamara claimed, the king of Fuladu himself was known to have slave origins in spite of his military achievements. ${ }^{20}$ Needless to say, the Kamara retorted that Penda was a member of a royal family, and that Musa's marriage had nothing to do with slave-master relations.

In reckoning status origins, some of the village elders, including many slave descendants, focused instead on the patrilineage of the Kamara. Even before abolition, slaves who were redeemed by, or who redeemed themselves from their masters, would earn rights over their children and were able to found their own lineages. Although former masters have often retained some rights and influence over the labour of their former slave women's children after abolition, they have not contested the legitimacy and autonomy of kome patrilineages. ${ }^{21}$ This has certainly prompted slave descendants to honour the memory of their ancestors as required by the dominant, patriarchal logic; hence the Kamara's emphasis on their patrilineage. A corollary of this has been the consolidation of a discourse on the origins of the male founder(s) of the family, who in the

20 The Balde, Musa Molo's descent group, did (and do) adopt an open marriage and assimilation policy whereby people of different statuses including slaves could be integrated as family members.

21 It is likely that Islamization, which increased during the twentieth century, further contributed to the transition to a patrilineal and patriarchal kinship. 
case of Kunda families corresponds to the person who first settled in the village (see also below). Nobody in Kunda was alleged to have owned Musa Kamara, though an aged noble woman reported rumours that Musa Kamara was a slave of a Malian chief, and that Mari Penda once travelled to Mali and presented that chiefly family with a large wad of banknotes in order to undo the socio-moral bondage that had "tied" his father to his master. ${ }^{22}$ I did not probe the Kamara with this version of the facts. I am, however, positive that they would have vehemently rejected it. The Kamara elders were sanguine about the fact that Musa was a nobleman, and not a destitute person, in Mali. Their father - Mari Penda - had told them that Musa had a noble patronym, ${ }^{23}$ but that the village elites did not trust him because he did not have a good Islamic education like clerical members of the various Kamara clans living in Kunda and surrounding villages. ${ }^{24} \mathrm{He}$ could not obtain a noble wife for his son because, as one of them said: "if the villagers don't know where you're from, they'll give you a slave woman". According to his sons, Mari Penda resented this discrimination against his father. As his marriage strategies show, he firmly believed in his nobility, or at least aspired to it, and thus tried to "keep slavery out of the family". He did not, however, openly confront the nobles; having grown wealthy and renowned, he tried not to overstep his boundaries. "He satisfied himself with redeemed slaves", as Demba, the head of the Kamara family in 2008, reported.

On the available evidence, it is difficult to ascertain whether Musa was a nobleman. Some noble elders in Kunda conceded that he might have been one, but then neutralised the Kamara's claims to nobility by cynically observing that Musa and his children married slave women. My own interpretation of the story is that, rather than a one-off event like the acceptance of a slave woman, the integration of Musa Kamara among slave descendants took place progressively. What situated Musa and his family among the komo was probably his inability/ unwillingness to marry outside that group, and to forge marriage alliances with Penda's kin (matrilateral cross-cousin marriage being a preferred practice in this part of the world). More than Musa's own marriage, the turning point was perhaps the marriage of his daughters to the kome families of Kunda and a nearby village respectively. Mari Penda subsequently received a bride from one such family.

However, my hypothesis of the gradual process of integration is an analytical version of the events, not the local one. Local memory is replete with different versions, speculations and sometimes puzzles about the "true origins" of the Kamara. Having purified their descent group from traces of slavery, the identity of the Kamara as slave descendants fundamentally rests on establishing the origin of their ancestors, Musa and Penda. This is where the Kamara were particularly determined to pursue their cause. If the noble origins of Musa were

22 This vicissitude, which was reported by another villager too, is not entirely clear. It is uncertain why Mari Penda would be attached to his father's master (father's line). One might speculate that Mari Penda wished to honour his father by redeeming him from bondage.

23 I chose the pseudonym Kamara precisely because, like the original name, it can be a noble patronym among Mande groups, including the Soninke. Soninke speakers who bear a non-Soninke patronym are likely to be slave descendants.

24 At the time, Islamization was still partial, and advanced Islamic education was a prerogative of the nobles, especially the clerics (moodinu). 
ascertained, there would be no reason to refuse their sons a freeborn woman. As we shall see, this compelled them to go further back in time and space in order to reconstruct the route followed by Musa, which villagers removed or glossed as a condition of strangerhood, even of slavery.

For most slave descendants, the claim that "my father was not a slave" is a toothless statement because pre-immigration genealogies and places of origins are usually forgotten. This is not solely because memories of places that most descendants of strangers like Musa Kamara never visited inevitably fade. It is also because the routes of migration are not paved on the cultural terrain of collective memory, and the places "where they come from" are not enshrined in the geography of ancestral homes narrated by oral historians. In order to understand the struggle for recognition of the Kamara it is therefore necessary to understand how diasporic memory is produced and appropriated by Kunda villagers.

\section{Routing Roots: Ancestral Migrations and the Production of Incommensurable Otherness}

With some exceptions, Soninke villages, including Kunda, were founded four to five generations ago. This roughly corresponds to the depth of genealogical memory among the Soninke. Villagers remember who the first settler of a given family was, and recollect the descendants he/she begot thereafter, but have little knowledge of previous kinship relations. Pre-immigration genealogical memories are extremely fuzzy, almost non-existent, even among more recent immigrants. Prior to the exodus, Bundu villages laid in a commercial corridor of the Upper Senegal and Gambia River Valleys. These communities had extensive linkages with the wider Soninke diaspora (Curtin, 1975: 68) which certainly played a role in the integration of relatives and other Soninke speakers moving to the newly founded villages in the Upper River during the first decades of the twentieth century. Progressively, however, social ties with the Eastern diaspora thinned out. Most of the genealogies that I collected among the freeborn contained few marriages with the East. Villagers mostly married local people.

It would be inaccurate to say that people in Kunda have forgotten their kin relations with Eastern communities. They have rather turned them into ancestral memories. At a broad, ethno-linguistic level, Upper River Soninke sometimes describe themselves as a specific branch of the Soninke diaspora called Kambianko (Gambian Soninke). When I asked my informants to tell me the history either of their village or of the Kambia Soninke, Bundu was the most frequently cited point of departure. Kunda villagers attributed displacement to King Bokar Saada Sy (1855-1885). Wars, hardship and persecution during his rule forced people to uproot themselves and descend to the Gambia valley. Some villages in the Upper River were eventually named after the Bundu villages, and are still governed by the same families. ${ }^{25}$

However documented in historical terms, the emphasis on displacement from Bundu must be understood in the light of the myth of origin of the Soninke.

25 Among others: Sabi, Numuyell and Julangel. 
Soninke speakers often refer to displacement in Bundu as Kanta kare, literally "Kanta is ruined". Kanta is thought to be located near Kumbi Saleh, the capital of the medieval Empire of Ghana or Wagadu (Eastern Mali) (seventh-twelfth century), and widely acknowledged to be the ancestral homeland of the Soninke diaspora. According to the myth (Meillassoux, Doucouré and Simagha, 1967), a snake (biida) bestowed gold on Wagadu (probably a symbol of the riches of the Medieval trans-Saharan trade with the Arabs). As the legend goes, the snake was killed by a young man whose beloved girlfriend had been offered as a sacrificial gift to the mythical monster. The sinful murder brought havoc to Wagadu, forcing people to disperse. This is the exodus that generated the Soninke diaspora as we know it today, with people stationing in certain areas for short or long periods, before moving on again. Though they differed considerably from one another in the amount of detail they could offer, many interlocutors, irrespectively of their age, gender and status, knew this legend and held it as a sort of cultural heritage. Indeed, when I asked about such events of the remote past (ganni), I was encouraged to visit griots, ${ }^{26}$ or people knowledgeable enough to detail the chain of emplacements and exoduses that led the Soninke, throughout the centuries, to settle in their present locations (these experts included slave descendants). Note that whereas in Western thought "place is one the most evocative and powerful imaginary aids for the artifices of memory: locus" (Creet, 2011: 8, italics in the original), Soninke diasporic memory also highlights movement and routes. That is to say, the Soninke convey a sense of historical continuity by linking "actual" to "ancestral" migrations, thus creating a sense of a shared destiny of alternate emplacement and dispersal. Actual recollection dissolves into oral tradition, and chronology is telescoped in favour of experiential continuity.

The ancestral memory of single descent groups or xabilanu operates in a similar way. Many families migrated from Bundu along with the founders of Soninke villages, or some time later, and thus belong in the history of the foundation of such villages. They can appropriate the history of dispersal as a history of their own making. Other freeborn families came to Kunda from different regions or have different trajectories of immigration. They do not feature in the most recent history of exodus from Bundu and the subsequent foundation of villages in the Upper River (which is manifested in their subordinate position vis-à-vis the chiefs and the founders), but they may still be regarded as having common ancestry with the village founders in a more distant time-space. ${ }^{27}$ The skilful griot is able to describe the legendary ancestors and the tradition (laada) linked to a patronym. He or she also associates patronyms with prominent dynasties in lands to the east of Gambia, usually in Mali. For example, a well-known griot told me that the Dukure of Gambisara, the village chiefs, never settled in Bundu; they came directly from a branch of the royal family of Jafunu, in South Western Mali. Another oral historian told me that the chiefly lineage of Kumbija, the Jawara, belonged to the royal family of nearby Kingi, then migrated to Bundu, and eventually descended to the Gambia. The Jawara of Sabi also claim to have come directly from Kingi, but belonged to clerical lineages (moodinu)

\footnotetext{
26 There are two types of griots among the Soninke. The jaaru (praise singers) can be of different statuses, usually leatherworkers (garanke). The geseru, oral historians and custodians of genealogies (of nobles), form a separate status group.

27 This mode of reconstructing immigration and settlement is deep-seated and widespread among Soninke communities (Pollet and Winter, 1971: 44-62).
} 
of the patronym. In addition, customary relations between patronyms, such as the joking relationship (kallungora) between families of different status groups, might be represented as an ancient tradition that has bound families since the time of Wagadu or some other place along the route. ${ }^{28}$ In short, a freeborn patronym is usually endowed with cultural capital fundamentally constructed around the idea of ancestry, as well as with social capital that locates a member of a xabila within the social landscape by means of customary relations. Once again, this modality of memory is implicitly diasporic, for it locates the origins of a given patronym almost invariably to the east of Gambia, closer to the mythical homeland of Wagadu, and often within a narrative of stepwise exodus from it. Descent is thus as much about territory and mobility as it is about blood.

Finally, in Soninke villages, there are families that have different ancestral roots and routes altogether but who still intermarry with the freeborn. Although some of them were not Soninke by origin, thanks to kinship ties and certified status origins they were eventually able to become assimilated as Soninke freeborn. ${ }^{29}$ A few have even managed to retain their ethno-cultural distinctiveness. For instance, one of the most prestigious Quranic schools in Sabi is run by a Jaxanke (or Jakhanke) whose father immigrated to the village at the beginning of the twentieth century. This man was an Islamic scholar who, according to today's elders, had no relatives in Sabi. It was thanks to his scholarly credentials that Suware could pass as a noble despite being a stranger. He successfully obtained a spouse from the Kaba, a noble and clerical family featuring amongst the founders of the village. This marriage was thus an act of recognition of his social and geographical roots. Today, nobody in Sabi doubts that Suware came from a noble and clerical family in Tanda, a precolonial kingdom in South Eastern Senegal. While the Suware have been able to maintain their ethnic distinctiveness and facilitated the settlement of other Jaxanke families in Sabi, their destiny is now united with that of noble Sabinko by multiple matrimonial alliances.

To summarise this far, claiming membership in a particular status group is claiming origins in a past remembered as both roots and routes. While, on the one hand, the freeborn have forgotten their pre-immigration genealogies, on the other, their linkages (actual or putative) with Eastern communities are still remembered as descent, both in the genealogical sense and in the spatial sense of having descended from Soninke homelands to the Gambia valley. Routes and roots that fall outside the main narratives of the Soninke diaspora may also be acknowledged, provided that there are ways of establishing connections with Soninke freeborn and/or of certifying them.

A corollary of this mode of reconstructing past mobility is that slave descendants are denied ancestry. Even for immigrants like Musa Kamara who were not enslaved by Kunda people, foreign origins are reduced to undifferentiated and incommensurable otherness. This is the essence of the sentence "if they don't know where you come from [socially and geographically], they'll give you

28 Pollet and Winter (1971: 58) remark that in Jafanu, royal families and the first settlers bestowed particular laada on noble latecomers as a way of weaving allegiances with them.

29 For example, some branches of the Kaba of Sabi and Sandaga were originally Jaxanke and, thanks to pre-migratory genealogical ties to some noble Sabinko, they merged with them. 
a slave woman". In contrast to actual slaves, becoming classified as a "slave" did not imply a complete depersonalization. Immigrants were able to preserve their patronym and founded their households and lineages. ${ }^{30}$ Unlike the Jaxanke scholar in Sabi, however, many immigrants did not have the attributes of freeborn status and could not preserve their alterity while being integrated into the host community. The Kamara thus rationalize their inclusion in the komo as the lack of Islamic education. By having "chosen" to integrate into the village as komo, their ancestry was removed and eventually excluded from the heritage of migration. As some freeborn informants conceded: "[Musa Kamara] was a nobleman, but then he married a slave woman".

\section{Appropriating and Reproducing Diasporic Memory}

The Kamara defy the dominant discourse on the incommensurable otherness of immigrants ranked as slaves. Having redeemed their genealogy from slavery, their quest for recognition is an attempt to resist the removal of their ancestry and to reinscribe it into the Soninke oral tradition of ancestral migrations. This strategy emerged clearly during my first interview with Demba, the oldest man of the Kamara in 2008, who was known as a good historian in Kunda. Before I started recording him, I explained that I had come to see him because I was told he was knowledgeable about the past, and because I was also interested in the history of his family. It was no surprise that Demba began his narration from the distant past (ganni), and proceeded by interweaving the migration of his family with that of the Gambian Soninke. Although there is little doubt that the interview setting as well as my requests influenced him, the way he inscribed the story of the Kamara in the dominant narrative of diaspora reveals clearly both the cultural politics of memory and the attempts of those excluded from it to manipulate it:

[My ancestors arrived here] step by step. They left Segu [Central Mali] and went to Wagadu - they stayed long in Wagadu. When Wagadu was no good any more, they left Wagadu and went to Kanta. When Kanta was ruined, our forebears met in the bush, and asked each other: "How is it over there?". They replied "Over there is destroyed". That is why the Soninke say "Kanta kare" to mean something disastrous happened. When they left Segu, they came to Bundu. Their stay in Bundu lasted long till war reached them. In

Bundu, they scattered, and some went to Tambacounda [Senegalese city near the eastern border of the Gambia]. In Tamba, they scattered again [... and came to the Gambia].

Later in the interview, Demba nuanced this story and changed the migratory paths slightly, while insisting on the unfair discrimination that his family suffered in Kunda. He countered the villagers' matrimonial policy on the basis of a putatively shared ancestry with the Soninke freeborn. Even if, by so doing, he hinted at the fact that the Kamara might have been of a different ethnicity, he stressed that the sharing of routes and emplacements in the past should stand as evidence that Musa Kamara was no stranger:

30 In some parts of the region, slaves adopted their masters' patronym, even though freeborn and slave lineages were kept separate. 
This village is deceptive. If they don't know you, if you come and just stay once, they will say "give him a slave woman". Since they don't know where you come from... there are many freeborn [turned slaves] in this village. They will say to them "those are kome".

If they don't understand your place of origin, it won't work. However, the place where our Soninko [i.e. Soninke nobles] come from - Loni3 - is the place where we used to be together. We left Loni, we went to Kayes ${ }^{32}$ [south-western Mali]. We and the Fulani [Pulaar speakers] established strong ties. The Fulani and our sisters married over there [...]. In that time, the Soninko and us left Loni...

In his narration, Demba resists categorization by the dominant classes, but he does so not so much by opposing the way origins are reckoned, as by disputing the outcome of such reckoning. He does not dismiss the dominant mode of remembering home and migration; but rather he manipulates it. This allows him to insert his family history into the migratory history and heritage of the Soninke, thus claiming full citizenship in their society. This is not mere rhetoric fed to the ethnographer. It is remarkable that, in an attempt to certify the high status of their grandfather, Demba and another member of his family paid visits to Musa Kamara's purported place of origin. On separate occasions, while they travelled overland to reach other countries in West Africa, they visited some villages located at some distance from Bamako. They spoke to the elders of the villages, and even though they could not establish exact genealogical links, they reportedly had confirmation that Kamara is a noble patronym in the region.

Unfortunately, however hard they try to reconstruct their ancestry in geographical and social space; the Kamara's alternative memories have limited social currency in Kunda. It seemed that a number of villagers of all statuses were familiar with the story of the Kamara as narrated by them, a sign that I was not the only one they had tried to persuade of their noble ancestry. At the same time, there was no sign that Demba or his brothers overtly campaigned for a different history on public occasions. To be sure, griots can manipulate the past in order to please their patrons. Although I was unable to attend a ceremony at the Kamara compound, griots would hardly miss the opportunity to sing and praise the patronym of this prominent family. In a different village, I once heard a griot addressing a kome woman by the surname of Kamara (an unrelated lineage to the above) during a wedding ceremony. The griot proclaimed that "Kamara are not komo!", and proceeded to narrate the epics of a royal Kamara family of Mali and Mauritania. Such praising of names, comprehensive of diasporic ancestry, did not of course turn the woman, who was in fact cooking for her former mistress, into a noble. Were her family to look for a marriageable partner for her son, such versions of the past would have no credibility. Genealogies, which are widely known and are much less malleable than mythical pasts, would be used to locate her in the social landscape, and if needed at all, the more "official" versions of ancestral history that I described above would be mobilised in support of certain claims of status. Likewise, in social domains like marriage allegiances, the Kamara's versions of the past still lack legitimacy.

31 I could not locate Loni on available maps. Demba probably referred to a location in Central Mali.

32 Note that this is where Mari Penda had strong commercial connections. 
Finally, even though describing the political economy that upholds this mode of memory production is beyond the scope of this essay, let me mention again that the narratives of immigration and genealogies of diasporic ancestry which regulate marriage relations are also central to the reproduction of the sociopolitical order. This makes them difficult to manipulate. Since the foundations of communities, such memories have been part and parcel of the ideological apparatuses of the freeborn ruling classes. By relying on existing forms of power, the colonial and postcolonial states have indirectly contributed to reproducing and reifying such narratives of the past. To mention but one example, the noble family (or families) that founded or conquered a village usually enjoy a right of inheritance over village chieftaincy. Despite austerity measures imposed by neoliberal international agencies having curtailed the resources that can be fed into such forms of state patronage, the current regime in the Gambia still requires the village elites to ensure governance at the local level and to channel votes to the ruling party (Bellagamba and Gaibazzi, 2008). Last but not least, high rates of emigration to foreign countries in the Upper River have only partially eroded the significance of status boundaries. Soninke communities have maintained strong transnational and translocal solidarities, in which group membership, and the normative predicaments of status origins that go with it, are important, if not enforced, in the everyday life of the migrants (Sy, 2000; Gaibazzi, forthcoming-a).

\section{Concluding Remarks: From Untraceable Past to Intractable Present}

Exploring the intricacies of mobility and status in a Gambian Soninke village, this article has shown that diasporic memory may sustain social hierarchies rather than bring emancipation from them. In this milieu, the memory of past migration crystallizes not only movements between geographical locations, but also those between social positions. For a number of villagers, the integration of their immigrant forebears in the village is remembered as an event, rather than as a process, centred on the marriage between them (or their children) and slave women. Remembering the point of arrival and integration is not merely the result of displacement. Displacement has affected most of the Soninke who moved from Eastern Senegal and Mali to the Upper River and founded new villages in the late nineteenth century. Moreover, many immigrants who settled in these villages and later became "slaves" were not necessarily forced migrants but people in search of economic opportunities. Today the descendants of both groups have only truncated genealogies and a poor recollection of their pre-migratory past. Yet the freeborn memorialize displacement within a series of historical and mythical exoduses that constitute the Soninke as an imagined community of descent and destiny. Some immigrants who have integrated as freeborn in Kunda and other Soninke villages are allowed to become part of this community of destiny even though they do not share the same descent. The descendants of immigrants integrated as komo are also Soninke ethnics today, and will remain such tomorrow, but they are aliened from their ancestors and ancestral homes. Their status as strangers is frozen: in a way, the sons and grandsons of such immigrants still marry "slave women" because the freeborn still "don't [want to] know where they came from". 
Slave descendants do not simply forget their forebears. As a work of power, diasporic memory in the Soninke milieu interrupts the routing of roots of immigrant strangers, placing their descendants among the people who have no ancestry. Slave descendants have no or little room to commemorate their routes and to cherish their places of origins, and are thus forced to borrow narratives and rely on the very same means of cultural production (e.g. griots) through which the freeborn articulate their visions of history. At the same time, they may actively manipulate the dominant historical canon in order to claim cultural citizenship in their community and/or to contest the expunction of their ancestors from social memory.

There are not, however, two opposing camps of freeborn and slave descendants, but a unique, plural and uneven field of memory production through which status identities are crafted and disputed. Within this field, subaltern voices - in this case, the alternative recollection and signification of the past - do not necessarily emerge as a deviation or rupture of hegemonic articulation, but as what Gyan Prakash (2000: 288) has called an intractability surfacing within the dominant discourse. The Kamara of Kunda embody this intractable presence in the social memory of Kunda migrations. For most slave descendants, marriages among the komo stand as self-evident proof of their status, regardless of their actual origins: "he was a noble, but then he married a slave woman". Having removed traces of servility and obligations to any former masters, the certification of the origins of the Kamara rests fundamentally on establishing the validity of claims to freeborn origins. The Kamara's version of their diasporic past shifts attention away from slave descent (especially matrilineal descent), and produces a dignified, "pure", ancestry in a faraway homeland. By insisting on finding their roots, the Kamara reproduce, on the one hand, the discourse on ancestry which excludes them, while on the other they reveal the arbitrariness of such discourse on certifiable origins, ultimately unveiling the violent, ambivalent nature of slave descent as a self-fulfilling prophecy. In this way, the Kamara stretch the boundary of status to its limits, and even straddle it, but cannot, as yet, transcend it. For their fellow villagers, they remain well-known strangers, external insiders, purified impure, slaves whom nobody can call slaves.

\section{References}

Appadurai Arjun (1996) Modernity at large: cultural dimensions of globalization, Minneapolis, University of Minnesota Press, 229 p.

Barrett Hazel R. (1988) The marketing of foodstuffs in the Gambia, 1400-1980: A Geographical Analysis, Aldershot, Avebury, 231 p.

Basch Linda, Glick Schiller Nina and Szanton Blanc Cristina (1994) Nations unbound: transnational projects, postcolonial predicaments, and deterritorialized nation-states, London, Routledge, $344 \mathrm{p}$.

Beedle Paul (1980) Citizens and strangers in a Gambian town, PhD Thesis, Cambridge, University of Cambridge.

Bellagamba Alice (2009) After abolition: metaphors of slavery in the political history of the Gambia, in Benedetta Rossi Ed., Reconfiguring slavery: West African trajectories, Liverpool, Liverpool University Press, pp. 63-84. 
Bellagamba Alice (2005) Slavery and emancipation in the colonial archives: British officials, slave-owners and slaves in the Protectorate of the Gambia (1890ca-1936), Canadian Journal of African Studies, 39 (1), pp. 5-41.

Bellagamba Alice (2004) Entrustment and its changing political meanings in Fuladu, the Gambia (1880-1994), Africa, 74 (3), pp. 383-410.

Bellagamba Alice (2002) Ethnographie, histoire et colonialisme en Gambie, Paris, L'Harmattan, $277 \mathrm{p}$.

Bellagamba Alice e Gaibazzi Paolo (2008) Nient'altro da votare. dinamiche di partecipazione politica e disillusione nella Repubblica del Gambia (Africa Occidentale), in Fabio Viti Ed., Dipendenza personale, lavoro e politica, Modena, Edizioni II Fiorino, pp. 46-79.

Botte Roger (1994) Stigmates sociaux et discriminations religieuses : I'ancienne classe servile au Futa Jaloo, Cahiers d'études africaines, 34 (133-135), pp. 109-136.

Bruijn Mirjam de and Pelckmans Lotte (2005) Facing dilemmas: Former Fulbe slaves in modern Mali, Canadian Journal of African Studies, 39 (1), pp. 69-95.

Clark Andrew (1999) From frontier to backwater: economy and society in the Upper Senegal Valley, West Africa, 1850-1920, Lanham, University Press of America.

Cohen Robin (1996) Diasporas and the nation-state: from victims to challengers, International Affairs, 72 (3), pp. 507-520.

Comaroff John and Comaroff Jean (1992) Ethnography and the historical imagination, Boulder, Westview Press, 337 p.

Creet Julia (2011) Introduction: The migration of memory and memories of migration, in Julia Creet and Andreas Kitzmann Eds., Memory and migration: multidisciplinary approaches to memory studies, Toronto, University of Toronto Press, pp. 3-27.

Curtin Philip (1975) Economic change in precolonial Africa; Senegambia in the era of the slave trade, Madison, University of Wisconsin Press, $363 \mathrm{p}$.

David Philippe (1980) Les navétanes : histoire des migrants saisonniers de I'arachide en Sénégambie des origines à nos jours, Dakar, Nouvelles Éditions africaines, $525 \mathrm{p}$.

Gaibazzi Paolo (forthcoming-a) The migration-slavery nexus in contemporary Gambian Soninke society: questioning spatial and social mobility, in Alice Bellagamba, Sandra Greene, Martin Klein with Brown Carolyn Eds., After abolition: new perspectives on the transformation of African slavery, Princeton, Markus Wiener.

Gaibazzi Paolo (forthcoming-b) Two Soninke 'slave' descendants and their family biographies, in Alice Bellagamba, Sandra Greene, Martin Klein with Brown Carolyn Eds., African voices on slavery and the slave trade, Cambridge, Cambridge University Press.

Gaibazzi Paolo (2012) The rank effect: post-emancipation immobility in a Soninke village, Journal of African History, 53 (2), pp. 215-234.

Gaibazzi Paolo (2010a) Migration, Soninke young men and the dynamics of staying behind (the Gambia), PhD Thesis, Milan, "Riccardo Massa" Department of Human Sciences and Education, University of Milano-Bicocca, 288 p. 
Gilroy Paul (1993) The black Atlantic: modernity and double consciousness, Cambridge, Harvard University Press, xi, 261 p.

Gomez Michael (1992) Pragmatism in the age of jihad: the precolonial state of Bundu, Cambridge, Cambridge University Press, 252 p.

Kaplan Caren (1996) Questions ofTravel: Postmodern Discourses of Displacement, Durham, Duke University Press, 238 p.

Klein Martin (2009) Slave descent and social status in Sahara and Sudan, in Benedetta Rossi Ed., Reconfiguring slavery: West African trajectories, Liverpool, Liverpool University Press, pp. 26-44.

Klein Martin (1998) Slavery and colonial rule in French West Africa, Cambridge, Cambridge University Press, $354 \mathrm{p}$.

Kopytoff Igor and Miers Suzanne (1977) African 'slavery' as an institution of marginality, in Suzanne Miers and Igor Kopytoff Eds., Slavery in Africa: Historical and Anthropological Perspectives, Madison, University of Wisconsin Press, pp. 3-83.

Lentz Carola (2006) Introduction, in Richard Kuba and Carola Lentz Eds., Land and the politics of belonging in West Africa, Leiden Boston, Brill.

Lévy-Bruhl Henri (1934) Quelques problèmes du très ancien droit romain (essai de solutions sociologiques), Paris, Les Éditions Domat-Montchrestien, 183 p.

Malkki Liisa (1995) Purity and exile: violence, memory, and national cosmology among Hutu refugees in Tanzania, Chicago, University of Chicago Press, xiv, $352 \mathrm{p}$.

Manchuelle François (1997) Willing migrants: Soninke labor diasporas, 18481960, Athens, London, Ohio University Press, James Currey, 371 p.

Meillassoux Claude (1986) Anthropologie de l'esclavage : le ventre de fer et $d^{\prime}$ 'argent, Paris, Presses universitaires de France, $375 \mathrm{p}$.

Meillassoux Claude, Doucouré Lassana et Simagha Diaowé (1967) légendent de la dispersion des Kusa (épopée Soninke), Dakar, IFAN, 133 p.

Nora Pierre (1984) Les lieux de mémoire, Paris, Gallimard, 1642 p.

Patterson Orlando (1982) Slavery and social death: a comparative study, Cambridge, Harvard University Press, 511 p.

Pelckmans Lotte (2011) Travelling hierarchies: Roads in and out of slave status in a Central Malian Fulbe network, Leiden, African Studies Centre, 317 p.

Pelckmans Lotte and Hohanou Eric (2012) History must be rewritten!: National histories of domestic West African slavery revisited, in Douglas Hamilton, Kate Hodgson and Joel Quirk Eds., Slavery, memory and identity: national representations and global legacies, London, Pickering \& Chatto, pp. 92-104.

Pollet Éric et Winter Grace (1971) La société Soninké (Dyahunu, Mali), Bruxelles, Éditions de l'Institut de sociologie, 566 p.

Prakash Gyan (2000)The impossibility of subaltern history, Nepantla: Views from South, 1 (2), pp. 287-294.

Republic of The Gambia (2006) The Gambia. Atlas of 2003 Population and Housing Census, Banjul, The Gambia Bureau of Statistics. 
Rodet Marie (2010) Mémoires de l'esclavage dans la région de Kayes, histoire d'une disparition, Cahiers d'études africaines, 50 (197), pp. 263-291.

Rodet Marie (2009) Les migrantes ignorées du Haut-Sénégal : 1900-1946, Paris, Karthala, $338 \mathrm{p}$.

Rossi Benedetta (2009) Introduction: rethinking slavery in West Africa, in Benedetta Rossi Ed., Reconfiguring Slavery: West African Trajectories, Liverpool, Liverpool University Press, pp. 1-25.

Ryang Sonia and Lie John (Eds.) (2009) Diaspora without homeland: being Korean in Japan, Berkeley, University of California Press, 229 p.

Simmel Georg (1964 [1908]) The Stranger, in Kurt Wolff Ed., The sociology of Georg Simmel, New York, Free press, pp. 184-189.

Spivak Gayatri (1988) Can the subaltern speak?, in Cary Nelson and Lawrence Grossberg Eds., Marxism and the interpretation of culture, Urbana, University of Illinois Press, pp. 271-303.

Swindell Kenneth and Jeng Alieu (2006) Migrants, credit and climate: The Gambian groundnut trade, 1834-1934, Leiden, Boston, Brill, 261 p.

Sy Yaya (2000) L'esclavage chez les Soninkés : du village à Paris, Journal des Africanistes, 70 (1-2), pp. 43-69.

Trouillot Michel-Rolph (1995) Silencing the past: power and the production of history, Boston, Beacon Press, $191 \mathrm{p}$.

Vaughan James (1977) Mafakur: a limbic institution of the Margi (Nigeria), in Suzanne Miers and Igor Kopytoff Eds., Slavery in Africa: historical and anthropological perspectives, Madison, University of Wisconsin Press, pp. 85-102.

Weil Peter (1984) Slavery, groundnuts and the European capitalism in the Wuli kingdom of Senegambia 1820-1930, Research in Economic Anthropology, 6, pp. 77-119. 


\section{Paolo Gaibazzi}

\section{Diaspora without Homeland: Slave Descendants and the Cultural Politics of Ancestry in the Upper Gambia River Valley}

This article investigates how memories of migration are used to maintain the status boundary between people of freeborn and slave descent in the Gambia. Based on ethnographic and historical research among the Soninke communities of the Upper River Region, the article shows that forgetting the roots and routes of slave descendants has been central to forging and remembering their servile status. While all villagers have foreign origins, slave descendants are stigmatized for lacking certified ancestry. Unlike the freeborn, they cannot inscribe their homelands and diasporic journeys in the local oral traditions and genealogies of immigration. By drawing on the case study of a family, the article also shows that slave descendants may dispute this collective amnesia and discusses the possibilities and limits of subaltern narratives vis-à-vis the hegemonic production of the past.

\section{Une diaspora sans patrie : descendants d'esclaves et politique culturelle de I'ascendance dans la haute vallée du fleuve Gambie}

Cet article examine comment la mémoire de la migration est utilisée pour maintenir les frontières entre statuts sociaux en Gambie, notamment entre les personnes de condition libre et les descendants d'esclaves. Basé sur des recherches ethnographiques et historiques parmi les communautés soninkés de la région de l'Upper River, I'article montre que l'oubli des origines et des parcours migratoires des descendants d'esclaves participe à la reproduction de leur condition servile. Bien que tous les villageois aient des origines étrangères, les descendants d'esclaves restent stigmatisés du fait de leur généalogie " inexistante ». Contrairement aux personnes de statut libre, ils ne peuvent pas inscrire localement leur histoire diasporique dans les traditions orales ni dans les généalogies de l'immigration. En s'appuyant sur l'étude de cas d'une famille d'origine servile, l'article montre également que les descendants d'esclaves peuvent contester cette amnésie. Nous examinons notamment les possibilités et les limites des récits " subalternes " vis-à-vis de la production hégémonique du passé.

\section{Una diáspora sin patria: los descendientes de esclavos y las políticas culturales de ascendencia en el Alto Valle del río Gambia}

Este artículo describe cómo la memoria de la migración se utiliza para mantener la frontera entre los descendientes de los nacidos libres y los descendientes de esclavos en Gambia. Apoyándose en una investigación etnográfica e histórica de comunidades Soninke de la Región Alta del Río Gambia, el artículo muestra que el olvido de las raíces y las rutas de los descendientes de esclavos ha sido fundamental en la reproducción de su condición servil. Mientras que todos los habitantes de las comunidades Soninke son de origen extranjero, los descendientes de esclavos son estigmatizados por su falta de una ascendencia certificada. A diferencia de los nacidos libres, estos no pueden inscribir ni su país de origen ni su recorrido por la diáspora dentro de las tradiciones orales locales y sus genealogías de la inmigración. Mediante la historia de una familia, el artículo también muestra que los descendientes de esclavos pueden desafiar esta amnesia colectiva, y analiza las posibilidades y límites de las narrativas subalternas en relación a la producción hegemónica del pasado. 